\title{
Immuno-hormonal network in postmenopausal women: disturbance in breast cancer patients
}

\author{
ANDREW GLUSHKOV ${ }^{1}$, ELENA POLENOK ${ }^{1}$, LYUDMILA GORDEEVA ${ }^{l}$, STELLA MUN ${ }^{1}$, \\ MIKHAIL KOSTYANKO ${ }^{2}$, ALEXANDR ANTONOV ${ }^{3}$, NATALIA VERZHBITSKAYA $^{4}$, ILGIZ VAFIN ${ }^{5}$
}

${ }^{1}$ Federal Research Center of Coal and Coal Chemistry of Siberian Branch of the Russian Academy of Sciences, Kemerovo, Russia ${ }^{2}$ Department of Organic and Physical Chemistry, Institute of Fundamental Sciences, Kemerovo State University, Kemerovo, Russia ${ }^{3}$ Department of Mammology, Regional Clinical Oncology Dispensary, Kemerovo, Russia ${ }^{4}$ Department of Pathoanatomy, Regional Pathologoanatomic Bureaus, Kemerovo, Russia ${ }^{5}$ Regional Center of Blood, Kemerovo, Russia

\begin{abstract}
Introduction: Antibodies to estradiol and progesterone (Es and $\mathrm{Pg}$ ) modulated their blood serum concentration and biological effects in immunized animals. Antibodies to membrane steroid receptors acted as hormone agonists or antagonists in cell cultures.

Material and methods: Here we studied the levels of Es and Pg, idiotypic immunoglobulin (Ig) Al and anti-idiotypic IgG2 specific to Es and Pg in the serum of postmenopausal women (82 healthy donors and 443 breast cancer patients).

Results: It was found that individual high ratios of $P g / E s(>4), \operatorname{IgA-PgI/IgA-EsI~(>~1)~and~}$ $I g G-P g 2 / I g G-E s 2(>1)$ were associated with low breast cancer risk $(O R=0.4-0.5)$. High ratios of IgA-Pg1/IgA-EsI and IgG-Pg2/IgG-Es2 were associated with a high Pg/Es ratio in healthy women but not in breast cancer patients. The levels of idiotypic IgA to benzo[a]pyrene correlated significantly with IgA-Es 1 and IgA-Pg1 levels in both compared groups. IgA-Pg1/IgA-Es 1 ratio correlated with IgG-Pg2/ $I g G-E s 2$ only in healthy women but not in breast cancer patients.

Conclusions: The normal immune-hormonal balance supports the real adaptation of the organism to environmental carcinogens and inhibits the initiation and promotion of carcinogenesis. The disturbance between certain elements of this network (immune-hormonal disbalance) could stimulate carcinogenesis. Further studies of immune-hormonal interaction could be helpful for understanding the pathogenesis of other carcinogen-induced steroid-dependent diseases in humans.
\end{abstract}

Key words: estradiol, progesterone, antibodies, breast cancer.

(Cent Eur J Immunol 2021; 46 (1): 68-75)

\section{Introduction}

The formation of DNA adducts with the mutagenic metabolites of benzo[a]pyrene (Bp) and estradiol (Es) is a critical event for breast carcinogenesis [1-4]. These lowweight compounds being conjugated with macromolecular carriers turn into haptens and are able to induce specific immune reactions. It was shown that antibodies (Abs) to $\mathrm{Bp}$, Es and progesterone (Pg) could modulate the levels of these compounds in the blood serum and some tissues after immunization of animals [4-8]. Previously the concept of immunological disbalance between Abs to chemical carcinogens and endogenous steroids stimulating and inhibiting the initiation and promotion events of carcinogenesis was postulated [9]. Associations of Abs to Bp, Es and Pg with breast and lung cancers were revealed [10, 11]. It was supposed that Abs to Es could stimulate but
Abs to Pg could inhibit the carcinogenesis by modifying the concentrations of these hormones in the blood serum, and corresponding anti-idiotypic Abs could act the same way by the binding to membrane Es and Pg receptors on the target cells. This assumption was confirmed partially by revealing the Abs specific to Es receptors (likely the anti-idiotypic Abs to Es) in the blood serum of breast cancer patients (BCP), which acted as Es agonists functioning as cancer-promoting factors [12].

However, the influence of specific Abs on the steroid hormones levels in the blood serum of healthy donors and cancer patients was not studied. The participation of Abs to environmental carcinogens in the modulation of hormone levels by specific Abs remained unknown.

The aim of this study was to reveal the expected cooperative actions of Abs to Es and Pg with the corresponding

Correspondence: Elena Polenok, Federal Research Center of Coal and Coal Chemistry of Siberian Branch of the Russian Academy of Sciences, Kemerovo, Russia, e-mail: egpolenok@mail.ru Submitted: 14.09.2018; Accepted: 21.02.2019 
anti-idiotypic Abs on the Es and Pg concentrations in the blood serum of postmenopausal healthy women (HW) and BCP. The concept of immune-hormonal network with participation of Abs to Bp will be proposed.

\section{Material and methods}

\section{Patients}

The study was performed in 525 non-smoking postmenopausal women, of whom 443 were primarily diagnosed with invasive breast cancer (BC) in the Regional Clinical Oncology Dispensary (Kemerovo, Russian Federation). Each case diagnosis was confirmed morphologically in the oncology dispensary. Data related to tumor size, grade, and stage were collected from surgical pathology reports. $82 \mathrm{HW}$ without breast pathology were included for comparison. The median ages of participants were 63 (ranging from 42 to 85 ) for BCP and 58 (ranging from 43 to 80 ) for HW.

The study protocol conforms to the ethical guidelines of the 1975 Declaration of Helsinki and was approved by the ethics committee of the Institute of Human Ecology of the Siberian Branch of the Russian Academy of Sciences (protocol No. 48/1). All women provided informed consent.

\section{Inclusion and exclusion criteria}

Inclusion criteria: for BCP group - patients with primarily diagnosed invasive breast cancer, non-smoking postmenopausal women, patients were aged over 40 years old; for control group - healthy postmenopausal women without breast pathology, non-smoking, women were aged above 40 years old.

Exclusion criteria: patients with other types of tumor, smoking women, young women under 40 years old.

\section{Immunoassay of idiotypic Abs1 and anti-idiotypic Abs2 to estradiol and progesterone}

Abs 1 and Abs2 to Es and Pg were detected by solid phase non-competitive enzyme-linked immunosorbent assays. Microtiter wells were coated with $2 \mu \mathrm{g} / \mathrm{ml}$ Es or Pg conjugated with bovine serum albumin (BSA) (Amresco, USA) in $100 \mu$ l of phosphate-buffered saline (PBS), $\mathrm{pH}$ 7.4 (Amresco, USA) at room temperature overnight for detection of Abs1. The Es-BSA conjugate was obtained from Sigma-Aldrich (Germany). Pg-BSA conjugate was obtained by conjugation of hemi-glutarate of 21-hydroxyprogesterone (Sigma-Aldrich, Germany) and BSA by the carbodiimide method. Analysis of anti-idiotypic Abs2 to Es and Pg (IgG-Es2, IgG-Pg2) was performed on commercial kits of ImmunoFA-Estradiol and ImmunoFA-PG (Immunotech, Russia) with monoclonal Abs against Es and Pg immobilized on plastic. Coated wells were blocked for
30 min in blocking buffer saline $(0.5 \%$ BSA in PBS, $0.05 \%$ Tween 20 ). The serum samples were diluted at 1/20 for Abs 1 and 1/100 for Abs2 in blocking buffer saline and were incubated with coated antigens (100 $\mu \mathrm{l} /$ well) for $1 \mathrm{~h}$ at $37^{\circ} \mathrm{C}$. Bound Abs were detected by goat anti-human immunoglobulin (Ig) A or IgG antibody labeled with horseradish peroxidase (1/10000 dilution, Novex, USA). After each assay step wells were washed 4-5 times with $250 \mu \mathrm{l} /$ well of washing buffer saline (PBS, $0.05 \%$ Tween 20). The amounts of bound Abs were determined through enzymatic reaction with the chromogenic substrate 3,3',5,5' -tetramethylbenzidine (TMB) (Sigma-Aldrich, Germany). The reaction was then terminated by addition of $2 \mathrm{~N} \mathrm{HCl}$ and absorbance was measured at $450 \mathrm{~nm}$. All measurements were conducted in duplicate.

The levels of Abs1 and Abs2 to Es or Pg were expressed in arbitrary units and calculated based on the following formula:

$$
\operatorname{Ig} \mathrm{A}(\mathrm{G})-\mathrm{X}=\left(\mathrm{OD}_{X-B S A}-\mathrm{OD}_{B S A}\right) / \mathrm{OD}_{B S A}
$$

where $X$ is Es or $\mathrm{Pg}, O D_{X-B S A}$ is the absorbance of the binding to hapten-BSA conjugate, $O D_{B S A}$ is the absorbance of the binding to BSA.

\section{Steroid hormones determination}

The concentrations of Es and Pg were determined using the commercial kits ImmunoFA-Estradiol and ImmunoFA-PG (Immunotech, Russia) according to the instructions for use.

\section{Statistics}

All statistical analyses were conducted using STATISTICA version 8.0 (StatSoft Inc., USA). Normality was evaluated by Shapiro-Wilk's W-test. The non-parametric $\chi^{2}$ test with Yates' correction was used for comparison of data. The relationship between the Abs levels and the steroids hormones was assessed using Spearman's rank correlation analysis. All statistical analyses were two-sided, and $p<0.05$ was considered statistically significant. ROC analysis was performed to determine the threshold values (cutoff) of Abs and steroid hormones [13]. The odds ratio (OR) was determined with the $95 \%$ confidence interval (95\% CI).

\section{Results}

\section{Serum levels of estradiol and progesterone and corresponding specific antibodies in postmenopausal healthy women and breast cancer patients}

The blood serum concentrations of Es and $\mathrm{Pg}$ and levels of specific $\operatorname{Ig} \mathrm{A}(\operatorname{Ig} \mathrm{A}-\mathrm{Es} 1$ and $\operatorname{IgA}-\mathrm{Pg} 1)$ and corresponding anti-idiotypic IgG (IgG-Es2 and IgG-Pg2) were studied in postmenopausal HW and BCP. The individual ratios Pg/Es, IgA-Pg1/IgA-Es1 and IgG-Pg2/IgG-Es2 were 
Table 1. Case numbers $(n)$ and frequencies $(\%)$ with low $(\leq)$ and high $(>)$ estradiol and progesterone (Es and Pg) concentrations (pmol/l) and $\mathrm{Pg} /$ Es ratios in the blood serum of postmenopausal breast cancer patients and healthy women

\begin{tabular}{|c|c|c|c|c|}
\hline \multirow{2}{*}{$\begin{array}{l}\text { Hormones, } \\
\text { hormone ratio }\end{array}$} & Breast cancer patients & Healthy women & \multirow[t]{2}{*}{$\chi^{2}(p)$} & \multirow{2}{*}{$\begin{array}{c}\text { OR } \\
(95 \% \mathrm{CI})\end{array}$} \\
\hline & $n(\%)$ & $n(\%)$ & & \\
\hline Es $\leq 200$ & $141(31.8)$ & $41(50.0)$ & $9.3(0.002)$ & $0.5(0.3-0.8)$ \\
\hline$>200$ & $302(68.2)$ & $41(50.0)$ & & $2.1(1.3-3.5)$ \\
\hline $\mathrm{Pg} \leq 800$ & $261(58.9)$ & $27(32.9)$ & $17.8(<0.0001)$ & $2.9(1.8-4.8)$ \\
\hline$>800$ & $182(41.1)$ & $55(67.1)$ & & $0.3(0.2-0.6)$ \\
\hline $\mathrm{Pg} / \mathrm{Es} \leq 4$ & $304(68.6)$ & $40(48.8)$ & $11.2(<0.0001)$ & $2.3(1.4-3.7)$ \\
\hline$>4$ & $139(31.4)$ & $42(51.2)$ & & $0.4(0.3-0.7)$ \\
\hline
\end{tabular}

calculated. ROC analysis was performed to determine the threshold values of studied Abs and steroid hormones (cutoff) between BCP and HW.

The frequencies of cases with low $(\leq)$ and high $(>)$ hormone concentrations and ratios in compared groups are shown in Table 1. High levels of Es (> $200 \mathrm{pmol} / \mathrm{l})$ were revealed in BCP more frequently $(68.2 \%)$ than in $\mathrm{HW}(50.0 \%, p=0.002, \mathrm{OR}=2.1)$. High levels of Pg $(>800 \mathrm{pmol} / \mathrm{l})$ in $\mathrm{BCP}$ were found more rarely $(41.1 \%)$ than in HW $(67.1 \%, p<0.0001, \mathrm{OR}=0.3)$. High Pg/Es ratios $(>4)$ were revealed in BCP more rarely $(31.6 \%)$ than in $\mathrm{HW}(51.2 \%, p<0.0001, \mathrm{OR}=0.4)$. It means that high Es concentration was associated with high $\mathrm{BC}$ risk, but $\mathrm{Pg}$ concentration was associated with low $\mathrm{BC}$ risk, as well as high personal $\mathrm{Pg} /$ Es ratio.
So the disruption of normal balance between Pg and Es levels was a critical event for the breast carcinogenesis.

The frequencies of cases with low $(\leq)$ and high $(>)$ studied Abs levels and ratios in compared groups are shown in Table 2. No associations of IgA-Es1 and IgA-Pg1 with $\mathrm{BC}$ were found. High individual IgA-Pg1/IgA-Es1 ratios $(>1)$ were found in $\mathrm{BCP}$ more rarely $(17.8 \%)$ than in $\mathrm{HW}(31.7 \%, p=0.006, \mathrm{OR}=0.5)$. High IgG-Es2 levels $(>3)$ were found more frequently in BCP $(71.6 \%)$ than in $\mathrm{HW}(59.8 \%, p=0.04$, OR $=1.7)$. High personal IgG$\mathrm{Pg} 2 / \mathrm{IgG}-\mathrm{Es} 2$ ratios $(>1)$ were revealed more rarely in $\mathrm{BCP}(19.6 \%)$ than in $\mathrm{HW}(37.8 \%, p=0.0005$, OR $=0.4)$. It means that the predominance of $\mathrm{IgA}-\mathrm{Pg} 1$ and $\mathrm{IgG}-\mathrm{Pg} 2$ levels over IgA-Es1 and IgG-Es2 was associated with low $\mathrm{BC}$ risk.

Table 2. Case numbers $(n)$ and frequencies $(\%)$ with low $(\leq)$ and high $(>)$ antibody levels and ratios in postmenopausal breast cancer patients and healthy women

\begin{tabular}{|c|c|c|c|c|}
\hline \multirow{2}{*}{$\begin{array}{l}\text { Antibodies, antibody ratios, } \\
\text { combination of ratios }\end{array}$} & \multirow{2}{*}{$\frac{\text { Breast cancer patients }}{n(\%)}$} & \multirow{2}{*}{$\frac{\text { Healthy women }}{n(\%)}$} & \multirow{2}{*}{$\begin{array}{l}\chi^{2} \\
(p)\end{array}$} & \multirow[t]{2}{*}{ OR $(95 \%$ CI $)$} \\
\hline & & & & \\
\hline 1.1. $\operatorname{IgA}-\mathrm{Es} 1 \leq 3$ & $243(549)$ & $41(50.0)$ & $0.5(0.49)$ & \\
\hline$>3$ & $200(45.1)$ & $41(50.0)$ & & \\
\hline 1.2. $\operatorname{IgA}-\mathrm{Pg} 1 \leq 2$ & $230(51.9)$ & $39(47.6)$ & $0.4(0.55)$ & \\
\hline$>2$ & $213(48.1)$ & $43(52.4)$ & & \\
\hline 1.3. $\operatorname{IgA}-\mathrm{Pg} 1 / \operatorname{IgA}-\mathrm{Es} 1 \leq 1$ & $364(82.2)$ & $56(68.3)$ & $7.5(0.006)$ & $2.1(1.3-3.6)$ \\
\hline$>1$ & $79(17.8)$ & $26(31.7)$ & & $0.5(0.3-0.8)$ \\
\hline 2.1. IgG-Es $2 \leq 3$ & $126(28.4)$ & $33(40.2)$ & $4.0(0.04)$ & $0.6(0.4-1.01)$ \\
\hline$>3$ & $317(71.6)$ & $49(59.8)$ & & $1.7(1.01-2.8)$ \\
\hline 2.2. $\mathrm{IgG}-\mathrm{Pg} 2 \leq 2$ & $211(47.6)$ & $43(52.4)$ & $0.5(0.49)$ & \\
\hline$>2$ & $232(52.4)$ & $39(47.6)$ & & \\
\hline 2.3. IgG-Pg2/IgG-Es $2 \leq 1$ & $356(80.4)$ & $51(62.2)$ & $12.1(0.0005)$ & $2.5(1.5-4.1)$ \\
\hline$>1$ & $87(19.6)$ & $31(37.8)$ & & $0.4(0.2-0.7)$ \\
\hline $\begin{array}{l}\text { 3.1. IgA-Pg1/IgA-Es } 1 \leq 1 \\
\text { IgG-Pg2/IgG-Es } 2 \leq 1\end{array}$ & $295(66.6)$ & $44(53.7)$ & $4.5(0.03)$ & $1.7(1.1-2.8)$ \\
\hline $\begin{array}{l}\text { 3.2. } \operatorname{IgA}-\mathrm{Pg} 1 / \operatorname{IgA}-\mathrm{Es} 1>1 \\
\mathrm{IgG}-\mathrm{Pg} 2 / \operatorname{IgG}-\mathrm{Es} 2 \leq 1\end{array}$ & $61(13.8)$ & $7(8.5)$ & $1.2(0.26)$ & \\
\hline $\begin{array}{l}\text { 3.3. } \operatorname{IgA}-\mathrm{Pg} 1 / \operatorname{Ig} \mathrm{A}-\mathrm{Es} 1 \leq 1 \\
\mathrm{IgG}-\mathrm{Pg} 2 / \operatorname{IgG}-\mathrm{Es} 2>1\end{array}$ & $69(15.6)$ & $12(14.6)$ & $0(0.98)$ & \\
\hline $\begin{array}{l}\text { 3.4. } \operatorname{IgA}-\mathrm{Pg} 1 / \operatorname{IgA}-\mathrm{Es} 1>1 \\
\text { IgG-Pg2/IgG-Es } 2>1\end{array}$ & $18(4.1)$ & $19(23.2)$ & $35.7(<0.0001)$ & $0.1(0.1-0.3)$ \\
\hline
\end{tabular}


However, it could be true only when high individual IgA-Pg1/IgA-Es1 ratio was combined with high IgG-Pg2/ IgG-Es2 ratio. This combination (3.4 in Table 2) was revealed in BCP more rarely $(4.1 \%)$ than in HW $(23.2 \%$, $p<0.0001, \mathrm{OR}=0.1)$. The $\mathrm{BC}$ risk increased $(\mathrm{OR}=1.7)$ when the levels of $\operatorname{IgA}-\mathrm{Pg} 1$ and $\mathrm{IgG} 2$ were lower than IgA-Es 1 and IgG-Es2 (combination of ratios 3.1). There were no significant differences between $\mathrm{BCP}$ and $\mathrm{HW}$ in the other possible combinations (3.1-3.2 in Table 2).

So the disruption of normal balance between $\operatorname{IgA}-\mathrm{Pg} 1$ and IgA-Es1 as well as between IgG-Pg2 and IgA-Es2 was a critical event for the breast carcinogenesis.

\section{Relationships between hormone concentrations and specific antibody levels in postmenopausal healthy women and breast cancer patients}

We studied the frequencies of low and high levels of Es and $\mathrm{Pg}$ and $\mathrm{Pg} /$ Es ratios depending on the low and high levels of the specific Abs and Abs ratios in postmenopausal HW and BCP.
There was no interconnection between hormone concentrations and ratio on the one hand and $\operatorname{IgA}$-Es 1 and IgA-Pg1 levels on the other hand in HW (Table 3). The high individual $\operatorname{IgA}-\operatorname{Pg} 1 / \operatorname{IgA}-\mathrm{Es} 1(>1)$ ratio was associated with a low concentration of Es $(<200 \mathrm{pmol} / \mathrm{l}, p=0.008)$ and with a high concentration of $\operatorname{Pg}(\geq 800 \mathrm{pmol} / \mathrm{l}, p=0.005)$ and with a high personal $\mathrm{Pg} / \mathrm{Es}$ ratio $(>4, p=0.001)$ in $\mathrm{HW}$.

Hormone concentrations and $\mathrm{Pg} / \mathrm{Es}$ ratio were not associated with IgG-Es2 levels in HW. High levels of IgG$\mathrm{Pg} 2(>2)$ were associated with high Pg concentration $(p=0.012)$ and high $\mathrm{Pg} / \mathrm{Es}$ ratio $(p=0.001)$ in HW. High individual IgG-Pg2/IgG-Es2 ratios ( $>1)$ were associated with low Es concentration and with high Pg concentration and high personal $\mathrm{Pg} /$ Es ratio in $\mathrm{HW}$.

The corresponding relationships in BCP had some differences (Table 4). There were no associations between $\operatorname{IgA}-\mathrm{Pg} 1 / \operatorname{Ig} \mathrm{A}-\mathrm{Es} 1(>1)$ ratio and hormone concentrations and ratio, unlike in HW. High levels of $\operatorname{IgG}-\mathrm{Pg} 2(>2)$ were associated with high Es concentration $(p=0.016)$ and low $\mathrm{Pg}$ concentration $(p=0.001)$ and low personal Pg/Es ratio

Table 3. Case numbers $(n)$ and frequencies $(\%)$ of low $(<)$ and high $(\geq)$ levels of estradiol and progesterone (Es and $\mathrm{Pg})(\mathrm{pmol} / \mathrm{l})$ and $\mathrm{Pg} / \mathrm{Es}$ ratios depending on low $(<)$ and high $(\geq)$ levels of the studied antibodies and antibody ratios in postmenopausal healthy women

\begin{tabular}{|c|c|c|c|c|c|c|}
\hline \multirow{2}{*}{$\begin{array}{l}\text { Antibodies, } \\
\text { antibody ratios }\end{array}$} & \multicolumn{2}{|c|}{ Es } & \multicolumn{2}{|c|}{ Pg } & \multicolumn{2}{|c|}{$\mathrm{Pg} / \mathrm{Es}$} \\
\hline & $<\mathbf{2 0 0}$ & $\geq \mathbf{2 0 0}$ & $<800$ & $\geq \mathbf{8 0 0}$ & $<4.0$ & $\geq 4.0$ \\
\hline Healthy women & $n(\%)$ & $n(\%)$ & $n(\%)$ & $n(\%)$ & $n(\%)$ & $n(\%)$ \\
\hline 1.1. $\operatorname{Ig} \mathrm{A}-\mathrm{Es} 1 \leq 3$ & $23(56.1)$ & $18(43.9)$ & $14(31.4)$ & $27(65.9)$ & $18(43.9)$ & $23(56.1)$ \\
\hline 1.2. $\operatorname{Ig} \mathrm{A}-\mathrm{Es} 1>3$ & $18(43.9)$ & $23(56.1)$ & $13(31.7)$ & $28(68.3)$ & $22(53.7)$ & $19(46.3)$ \\
\hline$p$ & \multicolumn{2}{|c|}{0.377} & \multicolumn{2}{|c|}{1.000} & \multicolumn{2}{|c|}{0.508} \\
\hline 2.1. $\operatorname{Ig} \mathrm{A}-\mathrm{Pg} 1 \leq 2$ & 17 (43.6) & $22(56.4)$ & $15(38.5)$ & $24(61.5)$ & $23(59.0)$ & $16(41.0)$ \\
\hline 2.2. $\operatorname{Ig} \mathrm{A}-\mathrm{Pg} 1>2$ & $24(55.8)$ & $19(44.2)$ & $12(27.9)$ & $31(72.1)$ & $17(39.5)$ & $26(60.5)$ \\
\hline$p$ & \multicolumn{2}{|c|}{0.376} & \multicolumn{2}{|c|}{0.435} & \multicolumn{2}{|c|}{0.124} \\
\hline 3.1. $\operatorname{Ig} \mathrm{A}-\mathrm{Pg} 1 / \operatorname{Ig} \mathrm{A}-\mathrm{Es} 1 \leq 1$ & 23 (39.7) & $35(60.3)$ & $25(43.1)$ & $33(56.9)$ & $36(62.1)$ & $22(37.9)$ \\
\hline 3.2. $\operatorname{Ig} \mathrm{A}-\mathrm{Pg} 1 / \operatorname{Ig} \mathrm{A}-\mathrm{Es} 1>1$ & $18(75.0)$ & $6(25.0)$ & $2(8.3)$ & $22(91.7)$ & $4(16.7)$ & $20(83.3)$ \\
\hline$p$ & \multicolumn{2}{|c|}{0.008} & \multicolumn{2}{|c|}{0.005} & \multicolumn{2}{|c|}{0.001} \\
\hline 4.1. IgG-Es $2 \leq 3$ & $18(54.5)$ & $15(45.5)$ & $10(30.3)$ & $23(69.7)$ & $14(42.4)$ & $19(57.6)$ \\
\hline 4.2. IgG-Es $2>3$ & $23(46.9)$ & $26(53.1)$ & $17(34.7)$ & $32(65.3)$ & $26(53.1)$ & $23(46.9)$ \\
\hline$p$ & \multicolumn{2}{|c|}{0.652} & \multicolumn{2}{|c|}{0.861} & \multicolumn{2}{|c|}{0.472} \\
\hline 5.1. $\mathrm{IgG}-\mathrm{Pg} 2 \leq 2$ & $17(51.5)$ & $16(48.5)$ & $20(46.5)$ & $23(53.5)$ & $29(67.4)$ & $14(32.6)$ \\
\hline 5.2. $\mathrm{IgG}-\mathrm{Pg} 2>2$ & $24(61.5)$ & $15(38.5)$ & $7(17.9)$ & $32(82.1)$ & $11(28.2)$ & $28(71.8)$ \\
\hline$p$ & \multicolumn{2}{|c|}{0.537} & \multicolumn{2}{|c|}{0.012} & \multicolumn{2}{|c|}{0.001} \\
\hline 6.1. IgG-Pg2/IgG-Es $2 \leq 1$ & $19(37.3)$ & $32(62.7)$ & $24(47.1)$ & $27(52.9)$ & $35(68.6)$ & $16(31.4)$ \\
\hline 6.2. IgG-Pg2/IgG-Es2 > 1 & $22(71.0)$ & $9(29.0)$ & $3(9.7)$ & $28(90.3)$ & $5(16.1)$ & $26(83.9)$ \\
\hline$p$ & \multicolumn{2}{|c|}{0.006} & \multicolumn{2}{|c|}{0.001} & \multicolumn{2}{|c|}{$<0.0001$} \\
\hline
\end{tabular}


Table 4. Case numbers $(n)$ and frequencies $(\%)$ of low $(<)$ and high $(\geq)$ levels of estradiol and progesterone (Es and $\mathrm{Pg})(\mathrm{pmol} / \mathrm{l})$ and $\mathrm{Pg} /$ Es ratios depending on low $(<)$ and high $(\geq)$ levels of the studied antibodies and antibody ratios in postmenopausal breast cancer patients

\begin{tabular}{|c|c|c|c|c|c|c|}
\hline \multirow{2}{*}{$\begin{array}{l}\text { Antibodies, } \\
\text { antibodies ratios }\end{array}$} & \multicolumn{2}{|c|}{ Es } & \multicolumn{2}{|c|}{$\mathbf{P g}$} & \multicolumn{2}{|c|}{$\mathrm{Pg} / \mathrm{Es}$} \\
\hline & $<\mathbf{2 0 0}$ & $\geq \mathbf{2 0 0}$ & $<800$ & $\geq \mathbf{8 0 0}$ & $<4.0$ & $\geq 4.0$ \\
\hline Breast cancer patients & $n(\%)$ & $n(\%)$ & $n(\%)$ & $n(\%)$ & $n(\%)$ & $n(\%)$ \\
\hline 1.1. IgA-Es $1 \leq 3$ & $73(30.0)$ & $170(70.0)$ & $140(57.6)$ & $103(42.4)$ & $169(69.5)$ & $74(30.5)$ \\
\hline 1.2. $\operatorname{Ig} \mathrm{A}-\mathrm{Es} 1>3$ & $67(33.5)$ & $133(66.5)$ & $121(60.5)$ & $79(39.5)$ & $135(67.5)$ & $65(32.5)$ \\
\hline$p$ & \multicolumn{2}{|c|}{0.499} & \multicolumn{2}{|c|}{0.605} & \multicolumn{2}{|c|}{0.719} \\
\hline 2.1. $\operatorname{Ig} \mathrm{A}-\mathrm{Pg} 1 \leq 2$ & $68(29.6)$ & $162(70.4)$ & $135(58.7)$ & $95(41.3)$ & $165(71.7)$ & $65(28.3)$ \\
\hline 2.2. $\operatorname{IgA}-\mathrm{Pg} 1>2$ & $72(33.8)$ & $141(66.2)$ & $126(59.2)$ & $87(40.8)$ & $139(65.3)$ & $74(34.7)$ \\
\hline$p$ & \multicolumn{2}{|c|}{0.392} & \multicolumn{2}{|c|}{0.999} & \multicolumn{2}{|c|}{0.172} \\
\hline 3.1. $\operatorname{Ig} \mathrm{A}-\mathrm{Pg} 1 / \operatorname{Ig} \mathrm{A}-\mathrm{Es} 1 \leq 1$ & $119(32.7)$ & $245(67.3)$ & $218(59.9)$ & $146(40.1)$ & $251(69.0)$ & $113(31.0)$ \\
\hline 3.2. $\operatorname{Ig} \mathrm{A}-\mathrm{Pg} 1 / \operatorname{Ig} \mathrm{A}-\mathrm{Es} 1>1$ & $21(26.6)$ & $58(73.4)$ & $43(54.4)$ & $36(45.6)$ & $53(67.1)$ & $26(32.9)$ \\
\hline$p$ & \multicolumn{2}{|c|}{0.355} & \multicolumn{2}{|c|}{0.442} & \multicolumn{2}{|c|}{0.849} \\
\hline 4.1. IgG-Es $2 \leq 3$ & $47(37.3)$ & $79(62.7)$ & $68(54.0)$ & $58(46.0)$ & $80(63.5)$ & $46(36.5)$ \\
\hline 4.2. IgG-Es2 $>3$ & $93(29.3)$ & $224(70.7)$ & $193(60.9)$ & $124(39.1)$ & $224(70.7)$ & $93(29.3)$ \\
\hline$p$ & \multicolumn{2}{|c|}{0.130} & \multicolumn{2}{|c|}{0.220} & \multicolumn{2}{|c|}{0.176} \\
\hline 5.1. $\mathrm{IgG}-\mathrm{Pg} 2 \leq 2$ & $79(37.4)$ & $132(62.6)$ & $106(50.2)$ & $105(49.8)$ & $132(62.6)$ & $79(37.4)$ \\
\hline 5.2. $\operatorname{IgG}-\mathrm{Pg} 2>2$ & $61(26.3)$ & $171(73.7)$ & $155(66.8)$ & $77(33.2)$ & $172(74.1)$ & $60(25.9)$ \\
\hline$p$ & \multicolumn{2}{|c|}{0.016} & \multicolumn{2}{|c|}{0.001} & \multicolumn{2}{|c|}{0.012} \\
\hline 6.1. IgG-Pg2/IgG-Es $2 \leq 1$ & $111(31.2$ & $245(68.8)$ & $201(56.5)$ & $155(43.5)$ & $241(67.7)$ & $115(32.3)$ \\
\hline 6.2. IgG-Pg2/IgG-Es $2>1$ & $29(33.3$ & $58(66.7)$ & $60(69.0)$ & $27(31.0)$ & $63(72.4)$ & $24(27.6)$ \\
\hline$p$ & \multicolumn{2}{|c|}{0.796} & \multicolumn{2}{|c|}{0.045} & \multicolumn{2}{|c|}{0.471} \\
\hline
\end{tabular}

Table 5. Correlations between levels of studied antibodies in postmenopausal breast cancer patients and healthy women

\begin{tabular}{lccccc}
\hline $\boldsymbol{x}$ & $\boldsymbol{y}$ & \multicolumn{2}{c}{ Breast cancer patients } & \multicolumn{2}{c}{ Healthy women } \\
\cline { 3 - 6 } & & \multicolumn{1}{c}{$\boldsymbol{\boldsymbol { r } _ { s } ( \boldsymbol { p } )}$} & $\boldsymbol{y}=\boldsymbol{a} \times \boldsymbol{x}+\boldsymbol{b}$ & $\boldsymbol{r}_{\boldsymbol{s}}(\boldsymbol{p})$ & $\boldsymbol{y}=\boldsymbol{a} \times \boldsymbol{x}+\boldsymbol{b}$ \\
\hline IgA-Bp1 & IgA-Es1 & $0.78(<0.0001)$ & $\mathrm{y}=0.69 \mathrm{x}+1.07$ & $0.77(<0.0001)$ & $\mathrm{y}=0.76 \mathrm{x}+0.92$ \\
IgA-Bp1 & IgA-Pg1 & $0.69(<0.0001)$ & $\mathrm{y}=0.46 \mathrm{x}+0.80$ & $0.65(<0.0001)$ & $\mathrm{y}=0.45 \mathrm{x}+1.20$ \\
\hline IgA-Es1 & IgA-Pg1 & $0.71(<0.0001)$ & $\mathrm{y}=0.53 \mathrm{x}+0.56$ & $0.75(<0.0001)$ & $\mathrm{y}=0.59 \mathrm{x}+0.71$ \\
\hline IgA-Pg1/IgA-Es1 & IgG-Pg2/IgG-Es2 & $0.11(0.021)$ & $\mathrm{y}=0.12 \mathrm{x}+0.65$ & $0.42(<0.0001)$ & $\mathrm{y}=0.69 \mathrm{x}+0.29$ \\
\hline
\end{tabular}

$(p=0.012)$. High individual $\operatorname{Ig} \mathrm{A}-\mathrm{Pg} 2 / \operatorname{Ig} \mathrm{A}-\mathrm{Es} 2$ ratio was associated with low Pg concentration $(p=0.045)$.

So the disruptions of normal hormonal balance and normal immune balance were interconnected critical events in the breast carcinogenesis.

\section{Interactions of antibodies to benzo[a]pyrene, estradiol and progesterone in postmenopausal healthy women and breast cancer patients}

Interactions between levels of antibodies to Bp, Es and Pg were studied (Table 5). Positive linear correlations were found between levels of IgA-Bp1 and IgA-Es1 and $\operatorname{IgA-Pg} 1$ in BCP and $\mathrm{HW}\left(r_{\mathrm{s}}=0.65-0.78, p<0.0001\right)$.
IgA-Es1 correlated with IgA-Pg1 in both compared groups $\left(r_{\mathrm{s}}=0.71-0.75, p<0.0001\right)$. IgA-Pg1/IgA-Es1 ratios in turn correlated with IgG-Pg2/IgG-Es2 in $\mathrm{HW}\left(r_{\mathrm{s}}=0.42\right.$, $p<0.0001)$. Interaction of these ratio in BCP was weaker $\left(r_{\mathrm{s}}=0.11, p=0.02\right)$.

It means that IgA-Bp1 could influence IgA-Es1 and $\operatorname{IgA}-\mathrm{Pg} 1$ formation and $\mathrm{IgG}-\mathrm{Pg} 2 / \mathrm{IgG}-\mathrm{Es} 2$ ratio in $\mathrm{HW}$. The influence of $\operatorname{IgA}-\mathrm{Bp} 1$ on $\mathrm{IgG}-\mathrm{Pg} 2 / \mathrm{IgG}-\mathrm{Es} 2$ ratio was disrupted in BCP.

\section{Discussion}

It is well known that proliferation of the normal and malignant mammary cells depends on cooperative genomic 
and non-genomic actions of Es and Pg on the corresponding cytoplasmic and membrane receptors [14-16]. It was shown that $\mathrm{Pg}$ could inhibit the proliferative effect of Es on the breast line cells and xenografts of mammary tumors [17]. Evidently that resulting action of Es and Pg in women depends on their balance in the blood serum. This proposition was confirmed by our first result: a high individual ratio $\mathrm{Pg} / \mathrm{Es}(>4)$ was observed in BCP $(31.4 \%)$ significantly more rarely than in $\mathrm{HW}(51.2 \%, p<0.0001)$. So we categorized the high $\mathrm{Pg} / \mathrm{Es}$ ratio in $\mathrm{HW}$ as "hormonal balance", and the low $\mathrm{Pg} /$ Es ratio in $\mathrm{BCP}$ as "hormonal disbalance".

Previously the associations of Abs to Es and Pg with breast cancer were described [11]. It was assumed that Abs to Es could stimulate but Abs to Pg could inhibit the carcinogenesis. This proposition was confirmed by our second result: high personal IgA-Pg1/IgA-Es1 ratios (>1) were observed in BCP significantly more rarely $(17.8 \%)$ than in $\mathrm{HW}(31.7 \%, p=0.006, \mathrm{OR}=0.5)$. Immunoanalysis of the corresponding anti-idiotypic Abs had shown that high individual IgG-Pg2/IgG-Es2 ratios (> 1) were found in BCP significantly more rarely (19.6\%) than in HW $(37.8 \%$, $p=0.005, \mathrm{OR}=0.4)$. It means that the predominance of IgA-Pg1 and IgG-Pg2 levels over the IgA-Es1 and IgG-Es2 levels was associated with breast carcinogenesis. The high IgA-Pg1/IgA-Es1 and IgG-Pg2/IgG-Es 2 ratios in HW could be considered as "immunological balance". The low ones in BCP could be considered as "immunological disbalance".

The model Abs against Es and Pg modulated their concentrations in the blood serum and biological effects in immunized animals [7, 8]. For example, the immunization against Es was the primary cause of anti-Es Ab formation and extended the interval between breast cancer cell implantation and tumor growth in rats [18]. The non-genomic effects of an anti-idiotypic $\mathrm{mAb}$ as an Es mimetic in female cells were described [19]. The model Abs against Es receptor (analog of anti-idiotypic Abs to Es) blocked the rapidly nongenomic effects of Es in breast cancer cells MCF7 associated with tumorigenicity [20]. Abs to Es receptor purified from BCP sera was able to induce MCF7 cell proliferation [12].

So it would be logical to assume that Es and Pg concentrations in the women's blood serum depended on specific Abs and corresponding anti-idiotypic Abs. Our third result confirmed this proposition. It was found that high individual $\mathrm{Pg} / \mathrm{Es}$ ratios $(>4)$ were revealed in $\mathrm{HW}$ with high IgA-Pg1/IgA-Es1 ratios being more frequent $(83.3 \%)$ than low $\mathrm{Pg} / \mathrm{Es}$ ratios $(16.7 \%, p=0.001)$. The same frequencies of the high and low $\mathrm{Pg} / \mathrm{Es}$ ratios in $\mathrm{HW}$ with the high IgG$\mathrm{Pg} 2 / \mathrm{IgG}-\mathrm{Es} 2$ ratios were $83.9 \%$ and $16.1 \%$ respectively $(p<0.001)$. It means that hormonal balance depends on immunological balance in HW.

In contrast to HW there were no associations between $\mathrm{Pg} / \mathrm{Es}$ ratios and IgA-Pg1/IgA-Es1 and IgG-Pg2/IgG-Es2 ratios in BCP. It means that immunological regulation of hormonal balance was disrupted. Evidently it was due to inversion of the studied $\mathrm{Ab}$ actions at the hormone level. Indeed, high IgA-Pg1/IgA-Es1 ratios were associated with low Es concentration $(<200 \mathrm{pmol} / \mathrm{l} ; 75 \%$ of cases $)$ and with high $\mathrm{Pg}$ concentration ( $\geq 800 \mathrm{pmol} / \mathrm{l} ; 91.7 \%$ ) in HW in contrast to high Es concentration $(\geq 200 \mathrm{pmol} / \mathrm{l} ; 73.4 \%)$ and low Pg concentration ( $<800 \mathrm{pmol} / \mathrm{l} ; 54.4 \%)$ in BCP. High IgG-Pg2/IgG-Es2 ratios were associated with low Es levels $(71.0 \%)$ and with high Pg levels $(90.3 \%)$ in HW in contrast to high Es levels $(66.7 \%)$ and low Pg levels $(69.0 \%)$ in BCP.

The interactions of $\mathrm{Bp}$ with Es in carcinogenesis were described: most of the Bp derivatives bound to Es receptors and several of them had estrogenic or antiestrogenic activity [21, 22], while Es promoted Bp-induced effects $[23,24]$. So it was interesting to study the interaction of Abs to Bp with Abs to Es and Pg. Here the strong linear positive correlations of IgA-Bp1 levels with IgA-Es1 and $\mathrm{IgA}-\mathrm{Pg} 1$ levels were revealed in $\mathrm{HW}$ and in BCP $\left(r_{\mathrm{s}}=0.65-0.78, p<0.0001\right)$. IgA-Pg1/IgA-Es1 ratios correlated with $\mathrm{IgG}-\mathrm{Pg} 2 / \mathrm{IgG}-\mathrm{Es} 2$ ratios in a medium manner in HW $\left(r_{\mathrm{s}}=0.42, p<0.0001\right)$. The same correlation was low but significant in BCP $\left(r_{\mathrm{s}}=0.11, p<0.0021\right)$. That means that formation of Abs to environmental $\mathrm{Bp}$ and to endogenous steroids are real interconnecting processes. The formation of idiotypic Abs1 and anti-idiotypic Abs2 to steroid hormones are interconnected only in $\mathrm{HW}$, but this relationship is disrupted in BCP. This disruption is perhaps the cause of disturbance of immune-hormonal relationships in breast carcinogenesis.

The hypothetical immuno-hormonal network is schematically shown in Figure 1.

Environmental chemical carcinogens $(\mathrm{Bp})$ penetrate into the bloodstream through the surface epithelium, reach the target cells, react with cytoplasmic receptors (AhR) and stimulate the activity of cytochrome P450 enzymes (CYP). The genotoxic Bp metabolites form the Bp adducts, inducing Abs-Bp1 synthesis. The serum Abs-Bp1 stimulate the penetration of environmental $\mathrm{Bp}$ into the blood serum and thus stimulate the malignization of the target cells. Anti-idiotypic Abs-Bp2 induced by Abs-Bp1 modulate the interactions between $\mathrm{Bp}$ and $\mathrm{Ab}-\mathrm{Bp} 1$. The mucosal $\mathrm{Ab}-\mathrm{Bp} 1$ bind the $\mathrm{Bp}$ and thus inhibit Bp transport into the target cells and the following malignization.

The stimulation of CYP by Bp leads to formation of Es metabolites and Es adducts. Es adducts induce the synthesis of Abs-Es1 and/or Abs-Pg1 depending on individual characteristics of the immune system. Abs-Es1 and Abs$\mathrm{Pg} 1$ modulate the serum concentrations of Es and Pg depending on the Ab1 levels and affinities. The cooperative biological action of Abs-Es1 and Abs-Pg1 (stimulation or inhibition of carcinogenesis promotion) depends on their personal ratio.

Anti-idiotypic antibodies Abs-Es2 and Abs-Pg2 induced by Abs-Es1 and Abs-Pg1 modulate the interactions between steroid hormones and specific Abs1. At the same 


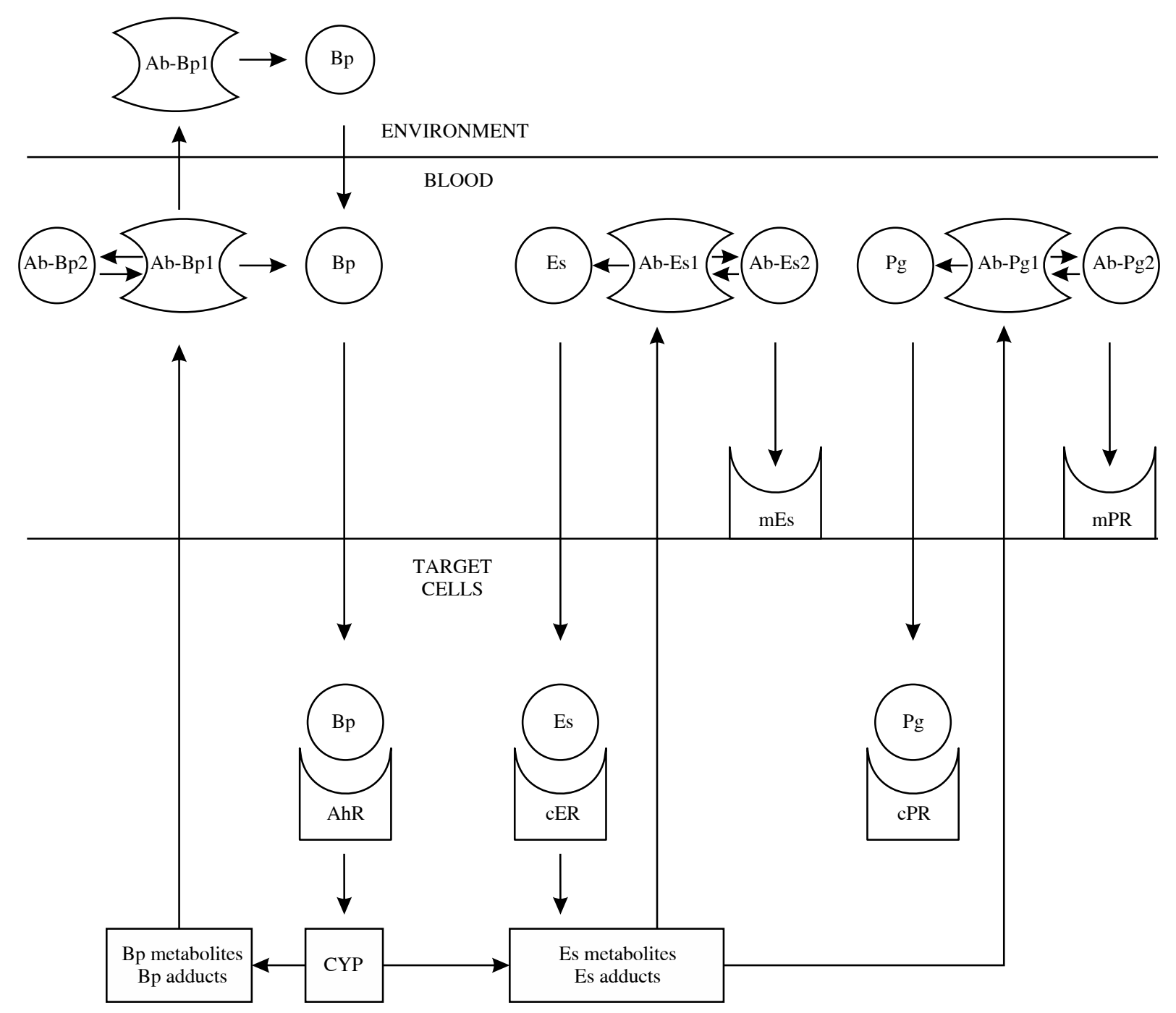

Fig. 1. Immuno-hormonal network induced by environmental chemical carcinogens (Bp - benzo[a]pyrene, Es - estradiol, $\mathrm{Pg}$ - progesterone, AhR - aryl hydrocarbon receptor, ER - estrogen receptor, PR - progesterone receptor, Ab-1 - antibodies, Ab-2 - anti-idiotypic antibodies, CYP - cytochrome P450 enzymes)

time Abs-Es2 and Abs-Pg2 react with membrane receptors (mER and $\mathrm{mPR}$ ). The following non-genomic effects mimicking the Es and Pg actions depend on $\mathrm{Ab}-\mathrm{Pg} 2 / \mathrm{Ab}-$ Es2 ratio.

Therefore, the immune-hormonal network consists of idiotypic and anti-idiotypic Abs specific to the environmental chemical carcinogens and to the endogenous steroid hormones, on the one hand, and steroid hormones with their cellular receptors, on the other hand. The normal immune-hormonal balance supports the real adaptation of the organism to the environmental carcinogens and inhibits the initiation and promotion of carcinogenesis. The disturbance between certain elements of this network (immune-hormonal disbalance) could stimulate carcinogenesis.
Further studies of immune-hormonal interaction could be helpful for understanding the pathogenesis of other carcinogen-induced steroid-dependent diseases in humans.

\section{Acknowledgments}

This study was funded by the Federal Agency of Scientific Organizations of Russia (State assignment No. 03522016-0001), project No. VI.59.1.1 of the Siberian Branch of the Russian Academy of Sciences.

The authors declare no conflict of interest. 


\section{References}

1. Rundle A, Tang D, Hibshoosh H, et al. (2000): The relationship between genetic damage from polycyclic aromatic hydrocarbons in breast tissue and breast cancer. Carcinogenesis 21: 1281-1289.

2. Ambrosone CB, Abrams SM, Gorlewska-Roberts K, Kadlubar FF (2007): Hair dye use, meat intake, and tobacco exposure and presence of carcinogen-DNA adducts in exfoliated breast ductal epithelial cells. Arch Biochem Biophys 464: 169-175.

3. Yager JD (2015): Mechanisms of estrogen carcinogenesis: The role of E2/E1-quinone metabolites suggests new approaches to preventive intervention - a review. Steroids 99: 56-60.

4. Cavalieri EL, Rogan EG, Zahid M (2017): Critical depurinating DNA adducts: Estrogen adducts in the etiology and prevention of cancer and dopamine adducts in the etiology and prevention of Parkinson's disease. Int J Cancer 141: 1078-1090.

5. Verdina A (2006): Carcinogen-modified DNA and specific humoral immunity toward carcinogen-DNA adducts. A review. Ann Ist Super Sanita 42: 189-194.

6. Grova N, Prodhomme EJ, Schellenberger MT, et al. (2009): Modulation of carcinogen bioavailability by immunisation with benzo[a]pyrene - conjugate vaccines. Vaccine 27: 4142-4151.

7. Hillier SG, Groom GV, Boyns AR, Cameron EH (1975): Effects of active immunisation against steroids upon circulating hormone concentrations. J Steroid Biochem 6: 529-535.

8. Elsaesser F (1980): Effects of active immunization against oestradiol-17 beta, testosterone or progesterone on receptivity in the female rabbit and evaluation of specificity. J Reprod Fertil 58: 213-218.

9. Glushkov AN (2014): Immunological disbalance in carcinogenesis. Med Hypotheses 83: 166-171.

10. Glushkov A, Polenok E, Kostyanko M, et al. (2016): Postmenopausal breast cancer risk in relation to antibodies specific to benzo[a]pyrene, estradiol and progesterone. Iran J Cancer Prev 9: e4212.

11. Glushkov AN, Polenok EG, Ustinov VA (2016): Immunomodulation of human carcinogenesis by the blood serum antibodies against benzo[a]pyrene, estradiol and progesterone. Open J Immunol 6: 67-72.

12. Maselli A, Capoccia S, Pugliese P, et al. (2016): Autoantibodies specific to estrogen receptor alpha act as estrogen agonists and their level correlate with breast cancer cell proliferation. Oncoimmunology 5: e1074375-2.

13. Hajian-Tilaki K (2013): Receiver operating characteristic (ROC) curve analysis for medical diagnostic test evaluation. Caspian J Intern Med 4: 627-635.

14. Colditz GA, Rosner BA, Chen WY, et al. (2004): Risk factors for breast cancer according to estrogen and progesterone receptor status. J Natl Cancer Inst 96: 218-228.

15. Dressing GE, Goldberg JE, Charles NJ, et al. (2011): Membrane progesterone receptor expression in mammalian tissues: a review of regulation and physiological implications. Steroids 76: 11-17.

16. Kampa M, Notas G, Pelekanou V, et al. (2012): Early membrane initiated transcriptional effects of estrogens in breast cancer cells: First pharmacological evidence for a novel membrane estrogen receptor element (ERx). Steroids 77: 959-967.

17. Mohammed H, Russell IA, Stark R, et al. (2015): Progesterone receptor modulates ERx action in breast cancer. Nature 523: $313-317$.
18. Caldwell BV, Tillson SA, Esber H, Thorneycroft IH (1971): Survival of tumors after immunization against oestrogens. Nature 231: 118-119.

19. Sömjen D, Kohen F, Lieberherr M (1997): Nongenomic effects of an anti- idiotypic antibody as an estrogen mimetic in female human and rat osteoblasts. J Cell Biochem 65: 53-66.

20. Chaudhri RA, Olivares-Navarrete R, Cuenca N, et al. (2012): Membrane estrogen signaling enhances tumorogenesis and metastatic potential of breast cancer cells via estrogen receptor- $\alpha 36$ (ER $\alpha 36)$. J Biol Chem 287: 7169-7181.

21. Charles GD, Bartles MJ, Zacharewski TR, et al. (2000): Activity of benzo[a]pyrene and its hydroxylated metabolites in an estrogen receptor-alpha reporter gene assay. Toxicol Sci 55: 320-326.

22. Hirose T, Morito K, Kizu R, et al. (2001): Estrogenic/antiestrogenic activities of benzo[a]pyrene monohydroxy derivatives. J Health Sci 47: 552-558.

23. Kang SC, Lee BM (2005): Effect of estrogen receptor (ER) on benzo[a]pyrene-DNA adduct formation in human breast cancer cells. J Toxicol Environ Health A 68: 1833-1840.

24. Chen Z, Zhang Y, Yang J, et al. (2011): Estrogen promotes benzo[a]pyrene-induced lung carcinogenesis through oxidative stress damage and cytochrome c-mediated caspase- 3 activation pathway in female mice. Cancer Lett 308: 14-22. 